Movement is collecting all documents and testimony about Nazi persecutions and the Austrian resistance movement in Austria from 1938 to 1945 . The Archive is especially searching for documents, photographs, and the testimony of eyewitnesses. It is also collecting material on the resistance movement among Austrian exiles. Anyone having such source materials is invited to get in touch with the Documentationsarchiv des Osterreichischen Widerstandes, Wien, Postamt 37, Postfach 63.

\title{
SPECIAL CONFERENCES AND EXHIBITS
}

The 1964 annual meeting of the Forschungsinstitut für den Donauraum was held at Linz from October 2 to 5,1964 . Most of the papers dealt with the general problem of "The Economy of the Danubian States and the West." They were published in Jahrgang 1965, No. 1-2, of Der Donauraum.

The twelfth meeting of the historical section of the Institut für Osterreichkunde was held at St. Pölten, Lower Austria, from April 11-15, 1965. In view of the six hundredth anniversary of the Vienna University, the general topic of "Rudolph IV and his Times" was chosen as the main theme for discussion. The principal address was given by Alphons Lhotsky, of the Institut für österreichische Geschichtsforschung, in Vienna. It was entitled "Rudolph IV. Problems involved in interpreting his Personality."

The Südosteuropa Society, of Munich, held its annual meeting in Bonn from May 3-5, 1965. The general theme of the conference was "Current German-Southeastern Europe Economic Problems."

A conference dealing with problems concerning the history of the Sudeten German minorities in Czechoslovakia was organized by the Collegium Carolinum. It met in Stuttgart on June 3-4, 1965.

The Arbeitsgemeinschaft für die Geschichte der Arbeiterbewegung in Osterreich organized an "International Scientific Conference on the History of the Labor Movement" which was held at Linz, Upper Austria, between August 18 and 25, 1965. At this meeting Rudolf Neck read a paper on "Linz in 
the History of Austrian Social Democracy." Norbert Leser discussed "Max Adler," and Günther Nenning talked on "The Beginnings of Catholic Social Reform."

A major exhibit commemorating the Congress of Vienna of 1814-1815 was on display at the Hofburg from June until October, 1965. Numerous historical objects and documents on loan from England, France, Denmark, and the Federal Republic of Germany were included in it. The exhibit was sponsored by the Austrian Federal Ministry of Education and the Verein für Museumfreunde.

\section{PUBLICATIONS}

Pursuant to its plans for the publication of a multi-volume history of Austria-Hungary from 1848 to 1918, the Committee for the History of the Austro-Hungarian Monarchy approached various interested historians in different countries to ask them for specific suggestions in regard to persons to be called upon to collaborate in the project. The committee has received such recommendations from Franco Valsecchi (Rome), Victor L. Tapié (Paris), Péter Hanák (Budapest), and Josef Polišenský (Prague). According to the Committee's plans, the various parts into which the study has been divided are each to have a whole volume allotted to them in which the entire era between 1848 and 1918 will be covered. The chapters in each volume will be written by authors from various countries. At a special meeting during the International Historical Congress in Vienna the chairman of the Committee, Hugo Hantsch, gave a report on how the editorial work is being planned to forty especially invited representatives from different countries (especially Hungary, Czechoslovakia, Yugoslavia, and Rumania).

In order to commemorate the six hundredth anniversary of the University of Vienna, a new publication series-Studien zur Geschichte der Universität Wien-was established. This new series will be published under the auspices of the Publications Committee of the Academic Senate of the University of Vienna, of which Heinrich Fichtenau is director. The first three volumes, which have already been published, are made up of essays on the history of the academic administration and of several faculties. Also on the occasion of the univer- 